\title{
An update on novel mechanisms of primary aldosteronism
}

\author{
Maria-Christina Zennaro ${ }^{1,2,3}$, Sheerazed Boulkroun ${ }^{1,2}$ and Fabio Fernandes-Rosa ${ }^{1,2,3}$ \\ ${ }^{1}$ INSERM, UMRS_970, Paris Cardiovascular Research Center - PARCC, 56, rue Leblanc, 75015 Paris, France \\ ${ }^{2}$ University Paris Descartes, Sorbonne Paris Cité, Paris, France \\ ${ }^{3}$ Assistance Publique-Hôpitaux de Paris, Hôpital Européen Georges Pompidou, Service de Génétique, Paris, France
}

Correspondence should be addressed to M-C Zennaro Email maria-christina.zennaro@ inserm.fr

\begin{abstract}
Primary aldosteronism (PA) is the most common and curable form of secondary hypertension. It is caused in the majority of cases by either unilateral aldosterone overproduction due to an aldosterone-producing adenoma (APA) or by bilateral adrenal hyperplasia. Recent advances in genome technology have allowed researchers to unravel part of the genetic abnormalities underlying the development of APA and familial hyperaldosteronism. Recurrent somatic mutations in genes coding for ion channels (KCNJ5 and CACNA1D) and ATPases (ATP1A1 and ATP2B3) regulating intracellular ionic homeostasis and cell membrane potential have been identified in APA. Similar germline mutations of KCNJ5 were identified in a severe familial form of PA, familial hyperaldosteronism type 3 (FH3), whereas de novo germline CACNA1D mutations were found in two cases of hyperaldosteronism associated with a complex neurological disorder. These results have allowed a pathophysiological model of APA development to be established. This model involves modifications in intracellular ionic homeostasis and membrane potential, accounting for $\sim 50 \%$ of all tumors, associated with specific gender differences and severity of PA. In this review, we describe the different genetic abnormalities associated with PA and discuss the mechanisms whereby they lead to increased aldosterone production and cell proliferation. We also address some of the foreseeable consequences that genetic knowledge may contribute to improve diagnosis and patient care.
\end{abstract}

\section{Key Words}

- primary aldosteronism

- aldosterone producing adenoma

- bilateral adrenal hyperplasia

- potassium channels

- calcium channels

- ATPase

- phenotypic variability

- genotype-phenotype correlation

- genetic susceptibility

- somatic mutations

- endocrine tumor

\section{Introduction}

Primary aldosteronism (PA) is the most common and curable form of secondary arterial hypertension, with an estimated prevalence of $\sim 10 \%$ in referred patients and $4 \%$ in primary care (Hannemann \& Wallaschofski 2012), but as high as $20 \%$ in patients with resistant hypertension (Calhoun et al. 2002, Douma et al. 2008). Increased aldosterone levels in PA are associated with increased cardiovascular risk compared with essential hypertension (Mulatero et al. 2013, Savard et al. 2013). Comparison of cardiovascular events in a large controlled cross-sectional study, involving 459 patients with PA and 1290 controls with essential hypertension, individually matched for sex, age, and office systolic blood pressure, showed an increased prevalence of left ventricular hypertrophy, coronary artery disease, nonfatal myocardial infarction, heart failure, and atrial fibrillation (Savard et al. 2013). The excess cardiovascular morbidity is related to blood pressure-independent cardiac remodeling (Rossi et al. 1997) and myocardial fibrosis (Freel et al. 2012), with left ventricular changes being reversible in the long-term with

Published by Bioscientifica Ltd. 
surgical or medical treatment of PA (Rossi et al. 2013). Vascular remodeling associated with aldosterone excess and duration of hypertension predict the outcome of adrenalectomy in patients with PA, emphasizing the importance of early diagnosis of unilateral forms of the disease (Rossi et al. 2008).

PA results from autonomous aldosterone production from the adrenal cortex. It is caused in the majority of cases by a unilateral aldosterone-producing adenoma (APA) or bilateral adrenal hyperplasia (BAH) and is often accompanied by hypokalemia. Aldosterone production from the zona glomerulosa (ZG) of the adrenal cortex is tightly controlled in an exquisite regulatory loop to maintain sodium and electrolyte homeostasis in the kidney. The main intracellular mechanism involved is calcium signaling, which is induced by both angiotensin II (AngII) and potassium, the major regulators of aldosterone biosynthesis (Spat \& Hunyady 2004). Increased calcium signaling affects many of the steps involved in aldosterone biosynthesis, including increased cholesterol availability and influx into the mitochondria, as well as stimulation of the expression of CYP11B2, coding for the enzyme aldosterone synthase (AS), catalyzing the final steps of aldosterone biosynthesis (Guagliardo et al. 2012a). AngII acts through the AngII type 1 receptor (AT1R) to stimulate inositol trisphosphate-dependent $\mathrm{Ca}^{2+}$ release from the endoplasmic reticulum. In addition, both AngII and $\mathrm{K}^{+}$ act by depolarizing the ZG cell membrane potential, leading to opening of voltage-gated calcium channels. Indeed, ZG cells have an intrinsic capacity to behave as electrical oscillators. In the $\mathrm{ZG}$, the main ionic conductance is that of $\mathrm{K}^{+}$, due to the expression of different types of $\mathrm{K}^{+}$channels. Thus, the cell membrane potential closely follows the equilibrium potential of $\mathrm{K}^{+}$over a large range of extracellular $\mathrm{K}^{+}$concentrations. Potassium channels thus play an important role in the pathogenesis of PA as they are central regulators of the ZG cell membrane potential, functioning as an extracellular potassium sensor. The concentration gradient of $\mathrm{K}^{+}$between the intracellular and extracellular space that is required for the establishment of the membrane potential is generated by the activity of the $\mathrm{Na}^{+}, \mathrm{K}^{+}$-ATPase. Elevation of extracellular $\mathrm{K}^{+}$concentration, decrease in intracellular $\mathrm{K}^{+}$concentration, inhibition of the $\mathrm{Na}^{+}, \mathrm{K}^{+}$-ATPase, or potassium channels all lead to cell membrane depolarization, allowing opening of voltage-dependent $\mathrm{Ca}^{2+}$ channels. The importance of the maintenance of the strongly negative resting membrane potential $(-80 \mathrm{mV})$ and intracellular calcium concentrations of ZG cells for physiological aldosterone production has recently been highlighted by the discovery of genetic alterations affecting proteins involved in the regulation of ZG cell membrane potential and ionic homeostasis in familial and sporadic forms of PA.

\section{Somatic mutations in APA}

Availability of high throughput next-generation sequencing technologies has allowed for comparison of whole-exome genetic alterations between germline DNA and DNA extracted from APA (somatic DNA). Recurrent somatic mutations in genes coding for ion channels (KCNJ5 (Choi et al. 2011) and CACNA1D (Azizan et al. 2013, Scholl et al. 2013)) and ATPases (ATP1A1 and ATP2B3 (Beuschlein et al. 2013)) regulating intracellular ionic homeostasis and cell membrane potential have been identified (Fig. 1). No germline mutations are found in patients harboring somatic mutations in APA (although a few germline mutations in KCNJ5 were recently described in patients with BAH (Murthy et al. 2014), see below). KCNJ5 encodes the $G$ protein-activated inward rectifier potassium channel GIRK4 (alternative protein name KIR3.4). All KCNJ5 mutations identified so far in APA, as well as different germline mutations identified in familial hyperaldosteronism type III (FH3) (see below), are located in exon 2; the most frequent of them are p.Gly151Arg and p.Leu168Arg, but less frequent ones located nearby have also been described (for an extensive list of identified mutations, see Gomez-Sanchez (2014) and Monticone et al. (2014)). All these mutations are located near or within the selectivity filter of GIRK4, which allows selective passage of potassium ions through the channel pore, and affect the ion selectivity of the channel. Increased sodium conductance leads to sodium influx into the cell with chronic cell membrane depolarization followed by opening of voltage-dependent calcium channels and activation of calcium signaling and aldosterone production. Transfection of different mutant channels into adrenocortical cells leads to increased CYP11B2 transcription and aldosterone production, as well as increased expression of two of the transcriptional regulators of CYP11B2, NURR1 (encoded by NR4A2) and NOR1 (encoded by NR4A3) (Monticone et al. 2012, Oki et al. 2012a). More recently, whole-exome sequencing in APA has identified recurrent somatic mutations in two members of the P-type ATPase gene family, namely ATP1A1 encoding the $\alpha 1$ subunit of the $\mathrm{Na}^{+}, \mathrm{K}^{+}$-ATPase and $A T P 2 B 3$, coding for the plasma membrane calciumtransporting ATPase 3 (PMCA3) (Beuschlein et al. 2013), as well as mutations in the CACNA1D gene, coding for

Published by Bioscientifica Ltd. 

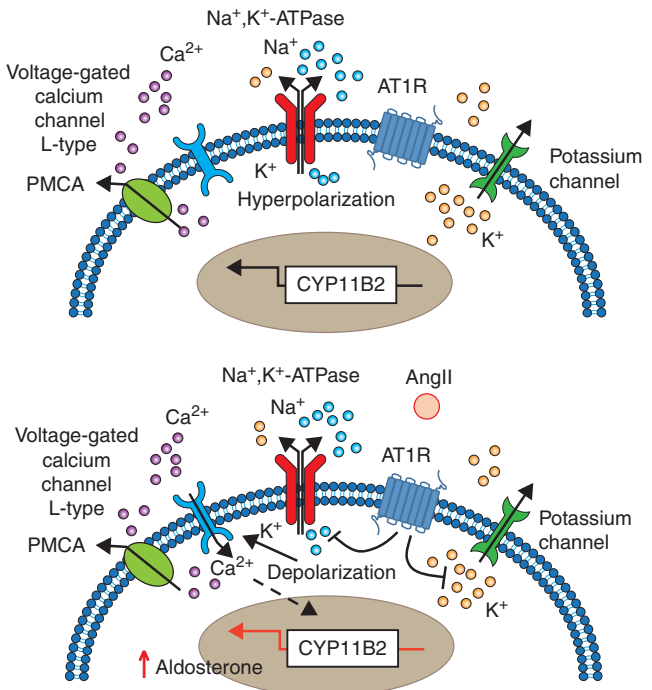

C

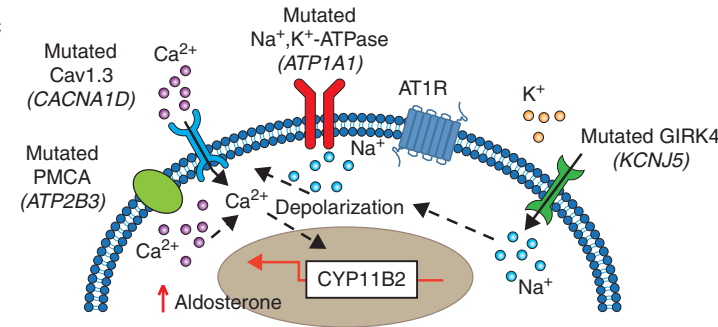

Figure 1

Aldosterone biosynthesis in normal and pathological conditions. (A) ZG cells have a very high conductance for $\mathrm{K}^{+}$, which maintains a strongly negative membrane potential under resting conditions $(-80 \mathrm{mV}$ with normal plasma $\mathrm{K}^{+}$concentrations) due to the expression of a large number of potassium channels. The concentration gradient of $\mathrm{K}^{+}$between the intracellular and extracellular space that is required for the establishment of the membrane potential is generated by the activity of the $\mathrm{Na}^{+}, \mathrm{K}^{+}$-ATPase. Elevation of extracellular $\mathrm{K}^{+}$concentration; decrease in intracellular $\mathrm{K}^{+}$concentration; inhibition of the $\mathrm{Na}^{+}, \mathrm{K}^{+}$-ATPase, or potassium channels all lead to cell membrane depolarization, allowing opening of voltage-dependent $\mathrm{Ca}^{2+}$ channels. (B) Angll acts through the Angll type 1 receptor (AT1R) to stimulate inositol trisphosphate-dependent $\mathrm{Ca}^{2+}$ release from the endoplasmic reticulum. In addition, both Angll and $\mathrm{K}^{+}$act by depolarizing the ZG cell membrane potential, leading to opening of voltage-gated $\mathrm{Ca}^{2+}$ channels, which ultimately leads to an increase in intracellular $\mathrm{Ca}^{2+}$ concentration. Angll triggers cell membrane depolarization by inhibiting potassium channels and the sodium potassium ATPase $\left(\mathrm{Na}^{+}, \mathrm{K}^{+}\right.$-ATPase). Increased intracellular $\mathrm{Ca}^{2+}$ concentration leads to the activation of the calcium signaling pathway, which triggers activation of specific transcription factors and positive regulation of CYP11B2 transcription. (C) Genetic alterations leading to cell membrane depolarization and intracellular ionic modification. KCNJ5 gain-of-function mutations affecting GIRK4 and ATP1A1 mutations of the $\mathrm{Na}^{+}, \mathrm{K}^{+}$-ATPase affect intracellular $\mathrm{Na}^{+}$ concentrations, leading to cell membrane depolarization triggering opening of voltage-gated $\mathrm{Ca}^{2+}$ channels. Mutations in ATP2B3 coding for the plasma membrane $\mathrm{Ca}^{2+}$-ATPase PMCA3 and mutations in CACNA1D, affecting the Cav1.3 subunit of the L-type voltage-gated calcium channel, have direct consequences on intracellular $\mathrm{Ca}^{2+}$ concentrations by affecting calcium recycling and influx. All genetic abnormalities ultimately lead to activation of $\mathrm{Ca}^{2+}$ signaling and increased aldosterone biosynthesis. Full arrow, direct activation; hatched arrows, indirect activation requiring intermediary steps. the $\alpha 1$ subunit of the Cav1.3 calcium channel (calcium channel, voltage-dependent, L type, alpha-1d subunit) (Azizan et al. 2013, Scholl et al. 2013). Mutations in the $\alpha 1$ subunit of the $\mathrm{Na}^{+}, \mathrm{K}^{+}$-ATPase affect particular residues in transmembrane helices M1 and M4 of the protein, involved in the interaction with $\mathrm{Na}^{+}$and/or $\mathrm{K}^{+}$, leading to a loss of pump activity and a strongly reduced affinity for $\mathrm{K}^{+}$, as well as to an inward proton or sodium leak, which increases aldosterone production through cell membrane depolarization and increased calcium influx, similar to what is observed in the presence of $\mathrm{KCNJ5}$ mutations (Azizan et al. 2013, Beuschlein et al. 2013). Ex vivo, electrophysiological measurements of primary cultured adenoma cells with different ATP1A1 mutations revealed inappropriate depolarization of cells with ATPase mutations (Beuschlein et al. 2013). In contrast, mutations of PMCA3 and Cav1.3 directly affect intracellular calcium homeostasis. PMCA3 mutations located in the highly conserved residues of transmembrane helix M4 are predicted to interact with $\mathrm{Ca}^{2+}$ and cause a major distortion of the calcium binding site, thus affecting intracellular calcium clearance. Somatic mutations in the Cav1.3 channel are located in particular segments known to form the channel activation gate, the voltage sensor, and the cytoplasmic domain coupling the voltage-sensing domain to the pore (Azizan et al. 2013, Scholl et al. 2013). Mutations result in gating changes suggesting gain-offunction mutations, in particular a shift of voltagedependent channel activation to more negative voltages, or to reduced inactivation of the channel, depending on the mutation, leading, similarly to ATP2B3 mutations, to alterations in intracellular calcium homeostasis.

Different studies have established the frequency of somatic mutations in cohorts with at least 100 patients with APA (Akerstrom et al. 2012, Boulkroun et al. 2012, Azizan et al. 2013, Beuschlein et al. 2013, Fernandes-Rosa et al. 2014, Kitamoto et al. 2014, Rossi et al. 2014). Among them, two subsequent multicenter studies, performed within the European Network for the Study of Adrenal Tumors (ENS@T, www.ensat.org), have investigated the genetic spectrum and clinical correlates of somatic mutations in APA (Boulkroun et al. 2012, Fernandes-Rosa et al. 2014). Analysis of 474 patients from seven centers has recently shown the presence of somatic mutations in $54 \%$ of APA, ranging from 27.2 to $56.8 \%$ across different centers. KCNJ5 mutations represent the most prevalent genetic abnormality and were found in 38\% of APA; ATP1A1 and ATP2B3 mutations were identified in 5.3 and $1.7 \%$ respectively (Fig. 2). Frequency of somatic mutations in $K C N J 5, A T P 1 A 1$, and $A T P 2 B 3$ is consistent with those

Published by Bioscientifica Ltd 


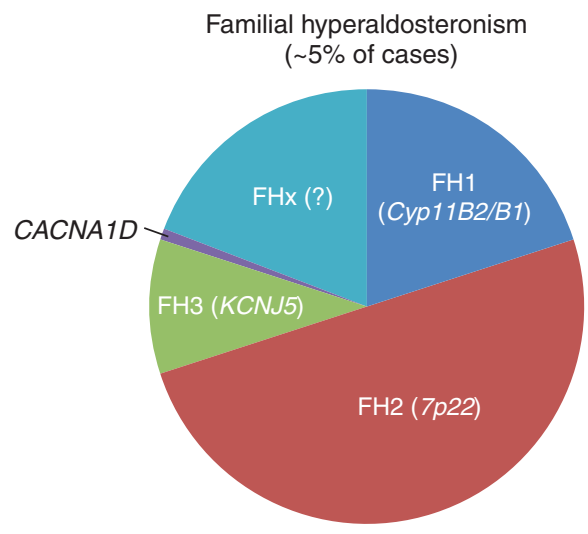

Germline mutations

Sporadic hyperaldosteronism ( $95 \%$ of cases)

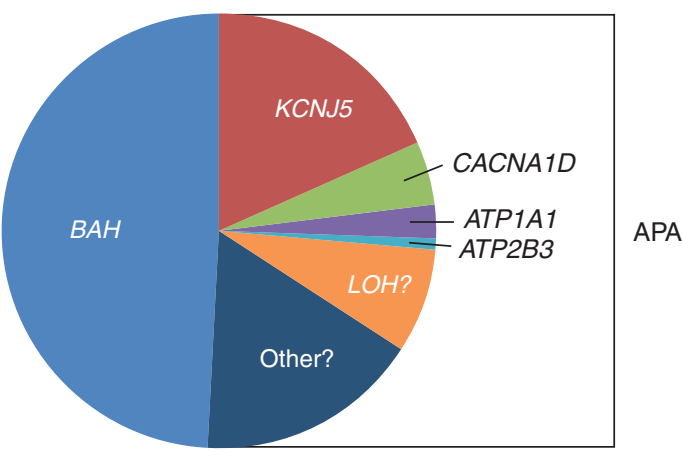

Somatic mutations in APA

\section{Figure 2}

(Upper panel) Three familial forms of PA have been described. FH1 is associated with a chimeric CYP11B1/11B2 gene, and FH3 with germline mutations in KCNJ5. FH2 is probably the most common form but without genetic abnormality identified so far. Germline de novo CACNA1D mutations have been identified in children with early-onset hypertension and hyperaldosteronism associated with a complex neurological disorder. Germline KCNJ5 variants have also been identified in a few cases of sporadic PA. Other Mendelian forms of familial hyperaldosteronism (FHx) may also exist. (Lower panel) In sporadic PA, recurrent somatic mutations in KCNJ5, CACNA1D, ATP1A1, and ATP2B3 are found in $>50 \%$ of APA. Other genes with point mutations or genomic rearrangements with loss of heterozygosity $(\mathrm{LOH})$ have yet to be described. No mutation has been identified in $\mathrm{BAH}$

previously reported in other cohorts (Azizan et al. 2013, Beuschlein et al. 2013, Williams et al. 2014), although KCNJ5 mutations may be more or less frequent in certain populations (Kitamoto et al. 2014, Rossi et al. 2014). In particular, it has been shown that the frequency of KCNJ5 mutations is higher in patients selected on more conservative criteria to define successful cannulation and lateralization during adrenal venous sampling than in centers adopting more permissive indices (Boulkroun et al. 2012). The frequency of KCNJ5 mutations is as high as
$70 \%$ in the series from Japan (Taguchi et al. 2012, Kitamoto et al. 2014). Mutations affecting CACNA1D were the second most prevalent genetic abnormalities being present in 9.3\% of cases (Fernandes-Rosa et al. 2014), higher than the previously described prevalence of CACNA1D in 5 to $7.8 \%$ of APA (Azizan et al. 2013, Scholl et al. 2013). Fernandes-Rosa et al. also identified ten novel CACNA1D mutations, implying the necessity of a large genotyping of CACNA1D in APA. Correlations of KCNJ5 and $C A C N A 1 D$ mutations with clinical and biochemical parameters (first analyzed in a subset of 199 patients from a single center and then replicated in two additional centers, to take into account between-center variability in the population structure) showed that patients with KCNJ5 mutations were more frequently female and diagnosed younger compared with CACNA1D mutation carriers or noncarriers (Fernandes-Rosa et al. 2014). CACNA1D mutations were associated with smaller adenomas. There was no association between the mutation status and preoperative plasma aldosterone or renin levels, the aldosterone-to-renin ratio, or the number of medications taken before surgery. There was also no association with outcome of post-operative blood pressure as measured by blood pressure and treatment score at follow-up, cure, or improvement of hypertension. In another large multicenter study, cases with ATP1A1 and $A T P 2 B 3$ mutations showed male dominance, increased plasma aldosterone concentration, and lower potassium levels (Beuschlein et al. 2013).

\section{Familial forms of PA and germline mutations in BAH}

While the majority of cases of PA are sporadic, $1-5 \%$ of cases are familial forms. Three different forms displaying Mendelian inheritance are described: familial hyperaldosteronism type I (FH1), type II (FH2), and type III (FH3). In addition, germline KCNJ5 mutations and de novo CACNA1D germline mutations were also described in patients with sporadic PA and unexplained early-onset hypertension and PA respectively (Scholl et al. 2013, Murthy et al. 2014).

\section{Familial hyperaldosteronism type I}

FH1, also called glucocorticoid-remediable aldosteronism (GRA), is a disease with autosomal dominant mode of inheritance described by Sutherland et al. (1966). The authors reported the case of a father and a son presenting clinical and biochemical findings of PA, which has been

Published by Bioscientifica Ltd 
relieved by treatment with dexamethasone. FH1 is characterized by early and severe hypertension, biochemical abnormalities of PA, significant production of the hybrid steroids 18-hydroxycortisol and 18-oxocortisol, bilateral hyperplasia or in rare cases adrenal nodules (Sutherland et al. 1966, New 1980). The clinical and biochemical characteristics of the affected patients are largely variable, which suggests that FH1 is a heterogeneous disease with a wide spectrum of presentations even within the same family group (Aglony et al. 2011). This variability in clinical presentation may be related to other hereditary factors that regulate blood pressure or environmental factors such as variations in dietary sodium intake. Thus, the family history in FH1 does not invariably reveal a history of severe hypertension in first-degree relatives of affected subjects.

The molecular etiology of FH1 is a crossover of genetic material between the highly homologous genes coding for AS (CYP11B2) and 11ß-hydroxylase (CYP11B1, responsible for the last steps of cortisol biosynthesis in the adrenal zona fasciculata (ZF)), creating a chimeric gene whereby the CYP11B1 promoter and CYP11B2-specific coding sequences are juxtaposed leading to an ectopic expression of AS in the ZF (Lifton et al. 1992). In FH1, the aldosterone biosynthesis is regulated by the adrenocorticotropin (ACTH), rather than by AngII, resulting in a circadian pattern of aldosterone production, which parallels that of cortisol production (Stowasser \& Gordon 2000).

In the hypertensive adult population, $\mathrm{FH} 1$ accounts for 0.5 to $1.0 \%$ of PA and occurs equally among women and men (Jackson et al. 2002, Pizzolo et al. 2005, Mulatero et al. 2011; Figure 2). However, in the pediatric population, a recent study has described a prevalence of $3 \%$ of the chimeric CYP11B1/CYP11B2 gene in hypertensive children (Aglony et al. 2011). Different crossover patterns of the hybrid gene have been described across different pedigrees, suggesting that the mutations arose independently (Dluhy \& Lifton 1995). More recently, an atypical gene segregation pattern has been described in four generations of a Chilean FH1 family. In this family, the chimeric CYP11B1/CYP11B2 gene segregation differs from an autosomal disease, showing $100 \%$ of penetrance in generations II and III and $62.5 \%$ in generation IV. The authors suggested that this inheritance pattern was not due to random segregation but due to a preferential segregation of the chimeric CYP11B1/CYP11B2 gene in the offspring (Carvajal et al. 2012). This may be explained by differential selection by viability of gametes, mitotic errors in germ cells, or differential survival of cells during development (Pardo-Manuel de Villena \& Sapienza $2001 a, b)$.

FH1 is a rare inherited disease with a variable degree of hypertension within and between pedigrees, sometimes misdiagnosed as essential hypertension. However, FH1 is associated with high morbidity and mortality at an early age. The diagnosis of FH1 must be considered in the presence of indicators of FH1: family history of hypertension and of cerebral hemorrhage before the age of 50 years (Litchfield et al. 1998), a history of hypertension from an early age ( $<20$ years), hypertension that has proven difficult to control and hypokalemia (Gates et al. 2001, Funder et al. 2008). The measure of the urinary levels of 18-oxocortisol and 18-hydroxycortisol, and the dexamethasone suppression test may be misleading for the diagnosis of FH1 (Fardella et al. 2001). The genetic diagnosis of FH1 is usually made by Southern blotting or long PCR techniques, both tests with high sensitivity and specificity for the diagnosis (Funder et al. 2008).

The Endocrine Society Clinical Practice Guideline recommends that FH1 should be treated with a glucocorticoid, preferably a synthetic glucocorticoid longer acting than hydrocortisone (Funder et al. 2008). The administration of exogenous glucocorticoids suppresses ACTH secretion and, therefore, reduces aldosterone levels and reverses the state of mineralocorticoid excess. In order to avoid complete suppression of the circadian regulation of cortisol and the development of iatrogenic Cushing's syndrome, the lowest possible dose of glucocorticoids that normalize blood pressure and/or serum potassium should be used (Funder et al. 2008). It has been shown that only partial suppression of ACTH with low dose glucocorticoids (dexamethasone $0.125-0.250 \mathrm{mg}$ /day or prednisone 2.5 or $5 \mathrm{mg} /$ day) is required to correct hypertension for several years, as demonstrated by the maintenance of normal echocardiographic parameters (Stowasser et al. 2000). The addition of an MR antagonist (eplerenone, spironolactone) could be useful in cases where blood pressure control is unsatisfactory. Eplerenone should be used in children to avoid glucocorticoid effects on growth or antiandrogenic effects of spironolactone (Funder et al. 2008). In addition to their increased cardiovascular risk, it has been shown that the carriers of the chimeric CYP11B1/CYP11B2 gene present increased left ventricular wall thicknesses and reduced diastolic function, well before the onset of hypertension (Stowasser et al. 2005). Also, subjects with FH1 present high serum levels of IL6, suggesting that inflammation plays a role in the blood pressureindependent cardiovascular damage occurring in the states of aldosterone excess (Staermose et al. 2009). These findings

Published by Bioscientifica Ltd. 
raise the question as to whether normotensive subjects found to have FH1 through familial genetic screening for FH1 would benefit from treatment with dexamethasone before the development of arterial hypertension (Staermose et al. 2009, Stowasser 2009).

\section{Familial hyperaldosteronism type II}

FH2 is a form of familial hyperaldosteronism first described by Gordon et al. (1991), not due to the presence of the chimeric CYP11B1/CYP11B2 gene and not remediable by glucocorticoids. Transmission is consistent with an autosomal-dominant mode of inheritance (Stowasser $\&$ Gordon 2000, 2001). The prevalence of FH2 ranges from 1.2 to $6 \%$ in adult populations of PA (Stowasser \& Gordon 2001, Medeau et al. 2005a, Mulatero et al. 2011, Pallauf et al. 2012). FH2 patients display a family history of PA and, within the same family, different subtypes of PA may be present (APA and BAH) with phenotypic variability (Stowasser \& Gordon 2001, Stowasser 2009, Mulatero et al. 2011). FH2 has been reported to be clinically and biochemically indistinguishable from sporadic forms of PA and is diagnosed on the basis of two or more affected family members (Medeau et al. 2005b, Mulatero et al. 2011).

The genetic background of FH2 remains unknown, but a linkage between $\mathrm{FH} 2$ and the chromosomal region 7 p22 has been established in some families; however, this linkage has not been observed in other $\mathrm{FH} 2$ families (Lafferty et al. 2000, So et al. 2005, Sukor et al. 2008). No mutations were found in different candidate genes located in this region, including retinoblastoma-associated Kruppel-associated box gene (RBAK), postmeiotic segregation increased 2 (PMS2), guanine nucleotide-binding protein $\alpha-12$ (GNA12), replication protein A3 (RPA3), zinc finger protein 12 (ZNF12), glucocorticoid-induced transcript 1 (GLCCI1), fascin 1 (FSCN1), and the cAMPdependent protein kinase type I $\beta$-regulatory subunit (PRKAR1B) (Medeau et al. 2005b, So et al. 2006, Jeske et al. 2008). Other candidate genes including CYP11B2, $A G T R 1$, and the p53 tumor-suppressor gene were also sequenced in $\mathrm{FH} 2$ patients and no mutations were identified (Ballantine et al. 1996a, b. Davies et al. 1997, Stowasser \& Gordon 2001).

Recently, particular germline KCNJ5 mutations have been found in patients with non-glucocorticoid-remediable PA, classified as FH2 (see below), due to a previously unknown phenotypic heterogeneity of FH3 (Mulatero et al. 2012). This implies that the genetic screening for KCNJ5 mutations should be considered in patients with mild forms of familial PA classified as FH2. Also, somatic KCNJ5 mutations have been reported in APA samples from patients classified as FH2 (Mulatero et al. 2012). Given the high frequency of PA among hypertensive subjects, these findings might be due to a causal association of sporadic PA in the same family. An alternative hypothesis could be a polygenic determinant of PA with a genetic background predisposing to familial PA that developed into an APA only in patients carrying somatic KCNJ5 mutations.

\section{Familial hyperaldosteronism type III}

FH3 was first described in 2008 in a father and two daughters with early-onset severe arterial hypertension refractory to medical treatment (between ages 4 and 7 years) and hypokalemia (Geller et al. 2008). They exhibited marked hyperaldosteronism, very high levels of the hybrid steroids 18-oxocortisol and 18-hydroxycortisol, and aldosterone production was not suppressed by dexamethasone treatment. All three individuals presented massive $\mathrm{BAH}$, needing bilateral adrenalectomy to control blood pressure. The pathology demonstrated massive hyperplasia of the adrenal cortex (Geller et al. 2008). Recently, the genetic background of $\mathrm{FH} 3$ has been elucidated and has been attributed to the mutation p.Thr158Ala in the KCNJ5 gene (Choi et al. 2011; Fig. 2). Similar to the somatic mutations in APA, this mutation is located near the GYG motif that confers GIRK4 $\mathrm{K}^{+}$selectivity. Functional studies have demonstrated that GIRK4_Thr158Alatransduced adrenocortical cells presented a loss in $\mathrm{K}^{+}$ selectivity and greater influx of $\mathrm{Na}^{+}$into the cytoplasm resulting in the depolarization of the plasma membrane, thereby activating voltage-gated $\mathrm{Ca}^{2+}$ channels, leading to accumulation of intracellular $\mathrm{Ca}^{2+}$. Increased intracellular $\mathrm{Ca}^{2+}$ activates the calcium signaling pathway resulting in the synthesis of steroidogenic enzymes and increased aldosterone production (Oki et al. 2012b).

Recent studies have described different germline KCNJ5 mutations in families with FH3. The severity of PA depends on the type of KCNJ5 mutation. Patients carrying the germline mutations p.Gly151Arg, identical to one of the recurrent mutations in APA, p.Thr158Ala and p.Ile157Ser, all presented a severe phenotype of PA and early-onset hypertension resistant to medical treatment (Charmandari et al. 2012, Scholl et al. 2012). On the other hand, affected members of three FH3 families carrying the KCNJ5 p.Gly151Glu mutation and affected members from one family carrying the KCNJ5 p.Tyr152Cys mutation exhibited a remarkably milder phenotype

Published by Bioscientifica Ltd. 
similar to FH2 (Mulatero et al. 2012, Scholl et al. 2012, Monticone et al. 2013). In vitro studies have demonstrated that, in a manner similar to other mutations, the mutation p.Gly151Glu alters GIRK4 selectively, resulting in $\mathrm{Na}^{+}$ influx and membrane depolarization. Electrophysiological studies demonstrated that the mutation p.Gly151Glu leads to a much larger $\mathrm{Na}^{+}$conductance than other mutations, resulting in rapid $\mathrm{Na}^{+}$-dependent cell lethality, which could limit adrenocortical cell proliferation and the severity of hyperaldosteronism in vivo. This finding may explain the milder phenotypes of families carrying p.Gly151Glu mutations and the absence of adrenal hyperplasia (Mulatero et al. 2012, Scholl et al. 2012). The notion of a strict genotype-phenotype correlation has however been challenged recently, with the description of a patient with sporadic hyperaldosteronism carrying a germline heterozygous p.Gly151Arg mutation, who had developed polyuria at 1.5 years of age and hypertension and hypokalemia by age 4 years. Thereafter, hyperaldosteronism was successfully treated for 7 years with spironolactone without visible adrenal enlargement (Adachi et al. 2014).

\section{Germline KCNJ5 and CACNA1D mutations in sporadic PA}

Recently, the coding region of KCNJ5 has been sequenced in peripheral blood DNA from 251 white subjects with apparently sporadic PA (Murthy et al. 2014). Three heterozygous missense mutations (p.Arg52His, p.Glu246Lys, and p.Gly247Arg) located outside the selectivity filter of GIRK4 were identified. In addition, $5 \%$ of PA patients carried a rare SNP (rs7102584, p.Glu282Gln), which presents a frequency of $2 \%$ in the 1000 genomes project. Functional studies demonstrated that, although outside the selectivity filter, the mutations p.Arg52His and p.Glu246Lys altered channel behavior in Xenopus oocytes and, in the H295R cells, depolarized the cell membrane and enhanced ATII-induced aldosterone synthesis and release (Murthy et al. 2014). In the same study, H259R cells transfected with GIRK4 channels carrying the SNP rs7102584 show reduced cell viability. In contrast, channels carrying the p.Gly247Arg mutation are functionally indistinguishable from the WT GIRK4. The authors suggest that germline variation in the KCNJ5 gene could play a role in the common sporadic form of PA (Murthy et al. 2014).

CACNA1D germline mutations were described in two subjects with early-onset hypertension, aldosteronism, and cerebral palsy (Scholl et al. 2013; Fig. 2). The first subject exhibited hypertension at birth, biventricular hypertrophy, elevated plasma aldosterone, high ARR, and hypokalemia at the age of 1 month. Other features included a seizure disorder, apparent cerebral palsy, cortical blindness, and complex neuromuscular abnormalities. No family history of early-onset hypertension or seizures was present. Treatment with a calcium channel blocker, amlodipine, normalized blood pressure. Genetic analyses identified a germline mutation in exon $8 \mathrm{~B}$ of CACNA1D introducing a missense mutation p.Gly403Asp. Somatic mutations of the same residue of CACNA1D (p.Gly403Arg) are found in APA (Azizan et al. 2013, Scholl et al. 2013, Fernandes-Rosa et al. 2014). Functional analysis of the p.Gly403Asp mutation demonstrated activation of Cav1.3 at less depolarizing potentials when compared with WT channel (Scholl et al. 2013). The second patient, diagnosed at birth with cerebral palsy and complex seizures, presented arterial hypertension, elevated plasma aldosterone, and suppressed PRA at the age of 5 years. Hypokalemia was noted at 8 years of age. Computed tomography (CT) scan showed no adrenal abnormality and there was no family history of early-onset hypertension or seizures. The patient carries a de novo germline mutation p.Ile770Met, which was also identified in APA samples. In HEK293T cells, p.Ile770Met Cav1.3 mutants showed maximum current amplitudes at less depolarized potentials and inactivation shifted to more hyperpolarized potentials (Scholl et al. 2013). The two germline mutations are predicted to increase intracellular $\mathrm{Ca}^{2+}$ concentration resulting in activation of the calcium signaling pathway and increased aldosterone production.

\section{Genetic abnormalities, cellular phenotype, and the origin of APA}

The current pathological diagnosis of APA is still difficult and is based on the description of yellow and wellcircumscribed nodules and/or hyperplasia in the resected adrenal gland associated with normalization of aldosterone levels after surgery. During the last few years, the detection of aldosterone producing cells has become an important issue, yet rendered difficult by the absence of specific antibodies directed against AS. Use of specific cRNA probes and in situ hybridization allowed detection of CYP11B2 expression in APA (Enberg et al. 2004, Lenzini et al. 2007, Boulkroun et al. 2010) and revealed that this was heterogeneous among tumor samples. Nishimoto et al. (2010) described for the first time the use of specific antibodies discriminating the AS and the 11ß-hydroxylase in human cells (Nishimoto et al. 2010) and confirmed the

Published by Bioscientifica Ltd. 
heterogeneity of AS expression in APA: some APA were composed of AS-positive cells, whereas some were of a mixed population of AS and 11 $\beta$-hydroxylase positive cells, and finally in some cases the expression of both enzymes was undetectable. More recently, generation of specific antibodies suitable for immunofluorescence has revealed that in APA a majority of cells express AS only, some cells express the $11 \beta$ - and $17 \alpha$-hydroxylases, but some cells are able to co-express the three enzymes (Nakamura et al. 2014). In 2013, two groups reported the use of specific antibodies against AS to improve the diagnosis of APA (Nanba et al. 2013, Volpe et al. 2013). However, similar to previous studies investigating CYP11B2 mRNA expression, in some APA AS is not detected. Semi-quantitative analysis revealed that AS expression was inversely correlated with tumor size and tumor volume, indicating that smaller tumors have higher AS expression per area and cell (Nanba et al. 2013, Ono et al. 2014). These results may explain: i) why small APA below the detection limit of CT can result in clinical hyperaldosteronism and ii) why AS expression was not detectable in some large APA. Thus the identification of other specific markers of the ZG is an important issue to confirm the pathological diagnosis for patients who undergo adrenalectomy for PA. Interestingly, all investigated APA expressed the 3 $\beta$-hydroxysteroid dehydrogenase, responsible for the conversion of pregnenolone into progesterone, independently of AS expression (Nishimoto et al. 2010, Ono et al. 2014). In the human adrenal, two $3 \beta$-hydroxysteroid dehydrogenase isoforms are expressed, namely HSD3B1 and HSD3B2 (Doi et al. 2010). Whereas peritumoral $Z G$ express both isoforms, APA express almost exclusively HSD3B2 (Doi et al. 2014); nevertheless, HSD3B2 mRNA is also expressed in cortisolproducing adenoma and in nonfunctioning adenoma (Sakuma et al. 2013), making it unsuitable for diagnosis. Other specific markers of ZG have been described, such as disabled-2 (dab2), specifically expressed in the ZG (Romero et al. 2007, Boulkroun et al. 2010) and involved in aldosterone secretion (Romero et al. 2007) and GIRK4 (Boulkroun et al. 2013); both are expressed in APA (Boulkroun et al. 2010, 2013) making them the potential candidates to improve APA diagnosis.

While aldosterone is synthetized by ZG cells, paradoxically APA are essentially composed of cells resembling those of the ZF (so-called ZF-like cells) with high cytoplasm-to-nucleus ratio. Nevertheless, despite their morphological appearance, ZF-like cells still express markers of the ZG cells such as CYP11B2, DAB2, or CD56, suggesting that adenoma cells derive from ZG (Boulkroun et al. 2010, 2011). In different studies, mutational status of the tumor has been shown to be correlated with its cellular composition and size: KCNJ5 mutations were associated with large ZF-like APA, while ATP1A1 and CACNA1D mutations were associated with small ZG-like APA, suggesting that adenoma size is associated with cellular composition (Azizan et al. 2012, 2013, Dekkers et al. 2014). Nevertheless, these associations were not replicated in a recent study investigating a large cohort of patients (Fernandes-Rosa et al. 2014), probably due to differences in the investigated population with a large proportion of ZF-like APA in the latter cohort. Remarkably, APA harboring KCNJ5 mutations are larger and those harboring CACNA1D mutations are smaller independent of their cellular composition (Fernandes-Rosa et al. 2014). The question on the origin of cells composing APA is still a matter of debate. Transcriptome analysis allowed researchers to identify a small set of differentially expressed genes between ZG- and ZF-like APA that in addition to CYP17A1 and CYP11B1 and the proportion of clear or compact cells (ZG-like APA are composed of at least $50 \%$ of compact cells) distinguish those tumors; it is interesting to note however that CYP11B2 expression does not allow discrimination between ZG- and ZF-like APA (Azizan et al. 2012).

While the functional link between genetic alterations and aldosterone production has been clearly established, the natural history of the development of APA is still unknown. Our actual knowledge does not allow explanation of the mechanisms involved in APA formation and their histological variability. Different hypotheses have been formulated: i) if APA derive from ZG cells, the ZF-like phenotype would be due to greater metabolic activity or induction of lipid uptake (Boulkroun et al. 2010, 2011); ii) if APA derive from ZF cells, AS expression would be due to the presence of a somatic mutation in identified or not yet identified genes (Azizan et al. 2012, 2013); iii) APA derive from aldosteroneproducing cell clusters (APCCs; Nishimoto et al. 2010). APCCs are AS-positive cell clusters of cuneiform or trapezoid shape located in the ZG and outer ZF that were reported recently in addition to the conventional adrenal cortex zonation (Nishimoto et al. 2010). They are formed of a mixed population of cells expressing CYP11B2, with cells located in the outer part of the structure co-expressing markers of the ZG, such as $D A B 2$, whereas cells in the inner part express markers of the ZF, such as CYP11B1 (Boulkroun et al. 2010, Nishimoto et al. 2010). This intermediate phenotype between ZG and ZF cells resembles what is observed in APA, suggesting that APA

Published by Bioscientifica Ltd. 
may originate from APCC (Boulkroun et al. 2010, Nishimoto et al. 2010). However, different gene expression profiles associated with different cellular compositions of APA and the large heterogeneity of APA at the transcriptome level rather support a model whereby APA originate from ZG cells that subsequently acquire some morphological characteristics of ZF.

Whereas adjacent adrenal cortex of cortisol-producing adenoma presents severe hypoplasia, we have shown that 'functional' ZG hyperplasia, increased nodulation, and decreased vascularization are the major features of adrenal cortex adjacent to APA (Boulkroun et al. 2010). This suggests that KCNJ5 mutations could indeed occur within a proliferating cortex, leading to growth advantage, clonal expansion, and tumor formation; alternatively, they may represent isolated events leading to APA formation, with adrenal cortex hyperplasia being secondary to reduced vascularization and/or tissue hypoxia. We have shown that KCNJ5 mutations are absent in somatic DNA from peritumoral cortices from adrenals carrying somatic KCNJ5 mutations in the corresponding APA (Boulkroun et al. 2012). Also, no correlation is observed between KCNJ5 mutations and parameters of adrenal cortex remodeling, suggesting that KCNJ5 mutations do not arise in a proliferative microenvironment propitious to promote a specific mutational event leading to APA formation. Moreover, different studies have reported the presence of multiple functional nodules expressing CYP11B2 in adrenals with APA (Enberg et al. 2004, Boulkroun et al. 2010, Dekkers et al. 2014). In multinodular adrenals, search for mutations in KCNJ5, ATP1A1, ATP2B3, and CACNA1D genes is usually performed on the principal nodule, i.e. the largest one. Recently, Deckers et al. have assessed the genotypic characteristics of multinodular adrenals. All identified mutations were detected on AS-positive nodules; interestingly, one multinodular adrenal contained two nodules harboring different recurrent KCNJ5 mutations (one p.Leu168Arg and the other p.Gly151Arg), suggesting independent genetic events leading to aldosterone overproduction.

To gain further insights into the potential mechanisms involved in the development of APA, different mouse models have been generated. Deletions of the KCNK3 and KCNK9 genes coding for the two-pore domain potassium channels task 1 and task3 lead to the development of different forms of hyperaldosteronism or low renin hypertension (Davies et al. 2008, Heitzmann et al. 2008, Guagliardo et al. 2012b, Penton et al. 2012). Genetic invalidation of task1 leads to adrenocortical cell depolarization and ectopic expression of CYP11B2 in ZF in female mice only, and to a glucocorticoid-remediable form of hyperaldosteronism resembling FH1 (Heitzmann et al. 2008). Deletion of task3 in mice results in hyperaldosteronism in young animals and low renin hypertension in adults (Penton et al. 2012, Bandulik et al. 2013). Task1 and task3 double knock-out mice display a phenotype reminiscent of idiopathic primary hyperaldosteronism due to BAH with elevated levels of aldosterone and low circulating renin, and failure to suppress aldosterone production by dietary salt ingestion (Davies et al. 2008). However, formation of adrenal tumors has never been observed in these models, indicating that other mechanisms are required to promote increased cell proliferation in APA. One potential mechanism could be the activation of the WNT/ $\beta$-catenin pathway. Indeed, it has been shown that this pathway is activated in $\sim 70 \%$ of APA (Boulkroun et al. 2011, Berthon et al. 2014), that in rare cases somatic activating mutations of CTNN1B, coding for $\beta$-catenin, have been described in APA (Azizan et al. 2013, Scholl et al. 2013) and that constitutive $\beta$-catenin activation in the adrenal cortex induces ectopic ZG differentiation and dedifferentiation of the orthotopic $\mathrm{ZF}$, resulting in hyperaldosteronism in 10-month-old mice (Berthon et al. 2010). However some of these mice develop malignant characteristics, such as uncontrolled neovascularization and local invasion, a phenotype rarely observed in patients with PA (Berthon et al. 2010); it is possible that the levels of $\beta$-catenin dosage play a role in the development of specific types of tumors within the adrenal cortex (Berthon et al. 2014).

Study of $\mathrm{K}^{+}$channel expression showed that about 90 different potassium channels are expressed in the adrenal cortex (Choi et al. 2011), results confirmed by our own data retrieved from transcriptome analysis performed on 11 control adrenals (Boulkroun et al. 2012; Table 1). Among them, the most expressed are KCNK3 and KCNK5, encoding respectively TASK1 and TASK2. In contrast to animal models, however (Heitzmann et al. 2008, Bandulik et al. 2010, 2013, Penton et al. 2012), to date no mutation in $K C N K 3$ has been reported in APA. Similarly, the low expression of $K C N K 9$, coding for TASK3, in human adrenal cortex is not in favor of a major role of this channel in the development of APA and no somatic mutations have been reported. Recently Lenzini et al. (2014) reported reduced expression of TASK2, encoded by KCNK5, in APA compared with normal adrenal cortex. The overexpression of a dominant-negative mutant of TASK2 resulted in an increase in aldosterone production due to increase in CYP11B2 and STAR expression in H295R cells.

Published by Bioscientifica Ltd 
Table 1 Potassium channel expression in human adrenal cortex. Expression data are derived from a previously described transcriptome analysis (Boulkroun et al. 2012). Values represent median centered, $\log _{2}$-transformed, and model-adjusted data. Expression is shown in $\log _{2}$ scale

\begin{tabular}{|c|c|}
\hline Gene & Expression \\
\hline KCNK3 & 52.01 \\
\hline KCNMB4 & 28.38 \\
\hline KCNJ8 & 21.3 \\
\hline KCNJ5 & 12.21 \\
\hline KCNJ9 & 11.89 \\
\hline KCNQ4 & 9.96 \\
\hline KCNC3 & 6.89 \\
\hline KCNK2 & 6.34 \\
\hline KCNQ1 & 4.87 \\
\hline KCNK5 & 4.61 \\
\hline KCNH2 & 4.16 \\
\hline KCNQ3 & 3.96 \\
\hline KCNK12 & 3.39 \\
\hline KCNK1 & 3.17 \\
\hline KCNT1 & 2.99 \\
\hline KCNJ14 & 2.83 \\
\hline KCNQ2 & 2.47 \\
\hline KCNJ11 & 2.33 \\
\hline KCNK15 & 2.25 \\
\hline$K C N A B 2$ & 1.85 \\
\hline KCNG2 & 1.85 \\
\hline KCNH6 & 1.62 \\
\hline $\mathrm{KCNH1}$ & 1.34 \\
\hline KCNK13 & 1.29 \\
\hline KCNH3 & 1.25 \\
\hline KCNN4 & 1.23 \\
\hline KCNE1L & 1.16 \\
\hline KCNK4 & 1.11 \\
\hline KCNC2 & 1.01 \\
\hline
\end{tabular}

\begin{tabular}{l} 
Gene \\
\hline$K C N D 3$ \\
KCNK9 \\
KCNG4 \\
KCNJ6 \\
KCNK6 \\
KCNA4 \\
KCNS3 \\
KCND2 \\
KCNF1 \\
KCNMB1 \\
KCNV1 \\
KCNA5 \\
KCNE1 \\
KCNN1 \\
KCNJ15 \\
KCNH7 \\
KCNJ1 \\
KCNJ2 \\
KCNB2 \\
KCNS2 \\
KCNMB2 \\
KCNH5 \\
KCNK7 \\
KCNK10 \\
KCNE2 \\
KCNV2 \\
KCNA6 \\
KCNN3 \\
KCNMA1 \\
\hline
\end{tabular}

\begin{tabular}{c}
\hline Expression \\
\hline 0.96 \\
0.95
\end{tabular}

0.95

0.90

0.89

0.87

0.81

0.81

0.80

0.80

0.75

0.75

0.74

0.72

0.69

0.69

0.68

0.64

0.64

0.64

0.63

0.61

0.60

0.59

0.58

0.58

0.57

0.56

0.54

\begin{tabular}{l}
\hline Gene \\
\hline KCND1 \\
KCNT2 \\
KCNC1 \\
KCNE4 \\
KCNAB1 \\
KCN16 \\
KCNK17 \\
KCNA1 \\
KCNA3 \\
KCNS1 \\
KCNH8 \\
KCNJ10 \\
KCNG3 \\
KCNE3 \\
KCNQ5 \\
KCN12 \\
KCNC4 \\
KCNMB3 \\
KCNJ13 \\
KCNJ4 \\
KCNB1 \\
KCNJ3 \\
KCNH4 \\
KCNA2 \\
KCNK16 \\
KCNA10 \\
KCNAB3 \\
KCNK18 \\
KCNA7 \\
\hline
\end{tabular}

\begin{tabular}{c}
\hline Expression \\
\hline 0.54 \\
0.53 \\
0.51 \\
0.50
\end{tabular}

0.49

0.48

0.48

0.48

0.47

0.46

0.45

0.44

0.44

0.44

0.43

0.41

0.41

0.41

0.40

0.38

0.38

0.38

0.37

0.35

0.35

0.33

0.32

0.31

0.29
However, considering the absence of phenotype in heterozygous models of task 1 and task 3 inactivation, it is unclear how decreased expression of TASK2 alone may result in APA (Gomez-Sanchez 2014). KCNJ5 is also found to be highly expressed in human adrenal cortex, explaining how mutations in this gene lead to APA formation. Interestingly, while GIRK4 is expressed in ZG and in APA, significantly lower levels were detected in APA harboring KCNJ5 mutations compared with APA carrying other types of mutations or a new mutation (Boulkroun et al. 2013). Reduced GIRK4 expression may therefore counterbalance increased sodium-dependent cell mortality that has been observed in vitro in presence of mutated GIRK4 channels (Mulatero et al. 2012, Scholl et al. 2012). This may play a role in the development of APA harboring GIRK4 mutations, in addition to previously described mechanisms protecting the cells from calcium-induced apoptosis (Williams et al. 2012).

The expression of a large number of $\mathrm{K}^{+}$and $\mathrm{Ca}^{2+}$ channels in normal adrenal and the identification of recurrent mutations in KCNJ5 and CACNA1D genes highlight the important role of the ionic homeostasis and intracellular calcium concentrations in physiological aldosterone production (Fig. 1). Evaluation of the expression of $\alpha$ subunits of $\mathrm{L}-, \mathrm{N}$-, and T-type calcium channels in normal adrenals revealed that at least two $\mathrm{Ca}^{2+}$ channel subunits, namely Cav1.3 (encoded by CACNA1D) and Cav3.2 (encoded by CACNA1H), were correlated with the mRNA levels of CYP11B2 (Felizola et al. 2014). High expression of these two channels in the human adrenal cortex has been recently reported (Scholl et al. 2013). It might be expected that mutations in other $\mathrm{K}^{+}$and $\mathrm{Ca}^{2+}$ channels, as well as ion pumps will be identified in the future, although at a lower frequency. In favor of this hypothesis is the fact that genome-wide transcriptome analysis has not revealed major differences in the molecular phenotype of KCNJ5-mutated tumors compared with nonmutated APA. This result indicates that, with a few possible exceptions, genetic abnormalities in APA all result in increased intracellular calcium concentrations and altered calcium signaling triggered by different ionic abnormalities.

Published by Bioscientifica Ltd. 


\section{Current clinical implications and future directions}

Familial forms of PA altogether represent $\sim 5 \%$ of cases, with genetic abnormalities identified only in FH1 (chimeric CYP11B2/B1 gene) and FH3 (KCNJ5). Recurrent somatic mutations in KCNJ5, ATP1A1, ATP2B3, and CACNA1D are found in more than half of APA. In addition, de novo CACNA1D germline mutations have been described in two subjects with a complex neurological disorder associated with PA, and functional germline KCNJ5 variants have been identified in a few subjects with sporadic PA (Fig. 1). While genetic diagnosis of recurrent KCNJ5, ATP1A1, ATP2B3 mutations is relatively simple and can be easily implemented in a hospital setting, the large number of different mutations in different regions of Cav1.3 implies the necessity of a large genetic screening of CACNA1D in APA.

Genotype-phenotype correlations have shown that patients with KCNJ5 mutations are more frequently female, diagnosed younger and with higher minimal plasma potassium concentrations, while the presence of CACNA1D mutations is associated with smaller adenomas (Fernandes-Rosa et al. 2014). An important clinical issue is whether the mutation status influences the final diagnosis of PA, the treatment options, and/or the therapeutic outcome. KCNJ5 mutations have been associated with a higher lateralization index at adrenal venous sampling, due to increased aldosterone production in the tumor side and more prominent contralateral suppression (Seccia et al. 2012). Thus, patients with KCNJ5 mutations could be more likely to be identified at adrenal vein sampling and therefore to receive adrenalectomy. However, these results were not replicated in a subsequent study that did not find evidence for a clinically important impact of mutation status on steroid gradients during adrenal venous sampling (AVS) (Osswald et al. 2013).

Cardiovascular complications of aldosterone excess in APA have been correlated with the mutational status in two studies comprising $>100$ patients (Kitamoto et al. 2014, Rossi et al. 2014), with slightly different results. Although the frequency of KCNJ5 mutations differed significantly between the studies (26\% in Rossi et al. (2014) vs $69.4 \%$ in Kitamoto et al. (2014)), higher plasma aldosterone levels were associated with the presence of KCNJ5 mutations. Rossi et al. identified more severe echocardiographic abnormalities (higher left ventricular mass index, LVMI) in KCNJ5 mutation carriers compared with noncarriers, with a more pronounced fall after adrenalectomy resulting in a similar regression of left ventricular hypertrophy in both groups (Rossi et al. 2014). Although no differences in left ventricular hypertrophy before surgery were identified by Kitamoto et al. (2014) LVMI was significantly improved following surgery in carriers of KCNJ5 mutations. In both studies, improvement in LVMI was independently associated with KCNJ5 mutations. These results underscore the importance of identifying young patients carrying KCNJ5 gene mutations, as such cases may be complicated by more prominent cardiovascular damage.

The knowledge of the pharmacology of mutant channels and pumps is useful for the interpretation of experimental and clinical data and might be relevant for the development of new therapies for APA. It has been demonstrated that somatic mutations of KCNJ5 confer a pathological $\mathrm{Na}^{+}$permeability to the mutated GIRK4 (Choi et al. 2011), which leads to ZG cell membrane depolarization and increased aldosterone production through a calcium-dependent mechanism (Monticone et al. 2012, Oki et al. 2012a). Increased intracellular calcium concentrations are supposed to be due to opening of voltage-activated $\mathrm{Ca}^{2+}$ channels. Interestingly, in the adrenocortical NCI-H295R cell line, high intracellular $\mathrm{Na}^{+}$impaired $\mathrm{Ca}^{2+}$ export via $\mathrm{Na}^{+} / \mathrm{Ca}^{2+}$ exchangers (NCX) and possibly allowed $\mathrm{Ca}^{2+}$ influx through NCX working in reverse transport mode (Tauber et al. 2014). Unlike WT GIRK4, which is inhibited by Tertiapin-Q (Jin et al. 1999), the mutant GIRK4 channels are only weakly inhibited by Tertiapin-Q (Tauber et al. 2014). Rather, in vitro studies have shown that the GIRK4 p.Leu168Arg mutant channel is inhibited by amiloride and, more potently, by the L-type $\mathrm{Ca}^{2+}$ channel blocker verapamil. The Gly151Arg and Thr158Ala mutants were also blocked by verapamil but less potently (Tauber et al. 2014). Verapamil may not only act on aldosterone secretion by directly blocking the mutated channel but also by inhibiting depolarization-activated voltage-gated $\mathrm{Ca}^{2+}$ channels. These findings point out the possible influence of the administration of verapamil on the diagnosis of PA, especially in patients with KCNJ5 mutations. Similarly, calcium channel blockers are used in the treatment of patients with PA; they have been shown to decrease not only blood pressure but also plasma aldosterone levels (Tanaka et al. 2007, Aritomi et al. 2012). In one of the two carriers of germline CACNA1D mutations (see above), the use of calcium channel blocker amlodipine normalized blood pressure and resolved biventricular hypertrophy (Scholl et al. 2013). These data raise the possibility of specific treatment in patients with KCNJ5 and CACNA1D mutations. It will be particularly relevant to identify

Published by Bioscientifica Ltd. 
surrogate biomarkers associated with the mutation status for stratifying patients for targeted treatment with verapamil or calcium channel blockers (alone or in association with amiloride) before surgery. In addition, it might be possible in the future to detect somatic mutations in circulating cell-free DNA derived from turnover of cells from APA. In particular for recurrent KCNJ5 mutations, which represent the majority of cases, this would represent a sensitive and noninvasive screening test for APA.

\section{Conclusion}

Application of next generation sequencing technologies has allowed us to move an enormous step forward in our understanding of the genetic and mechanistic basis of sporadic and familial forms of PA. It can be expected that further studies in a larger number of samples will provide the missing elements allowing explanation of the remaining 50\% of sporadic APA as well as the familial forms of PA without genetic defect identified so far. Other important questions that remain to be addressed by future research are whether there are susceptibility genes promoting the development of bilateral forms of PA and whether there are some common mechanisms involved in APA formation and $\mathrm{BAH}$ that are involved in adrenal cortex cell proliferation and/or aldosterone production.

\section{Declaration of interest}

The authors declare that there is no conflict of interest that could be perceived as prejudicing the impartiality of this review.

\section{Funding}

This work was funded through institutional support from INSERM and by the Agence Nationale pour la Recherche (ANR Blanc 2011, No.: 11-BSV1 005 03), the Fondation pour la recherche médicale (ING20101221177), the Fondation pour la Recherche Médicale (ING20101221177), the Programme Hospitalier de Recherche Clinique (PHRC grant AOM 06179), and by grants from INSERM and Ministère Délégué à la Recherche et des Nouvelles Technologies.

\section{References}

Adachi M, Muroya K, Asakura Y, Sugiyama K, Homma K \& Hasegawa T 2014 Discordant genotype-phenotype correlation in familial hyperaldosteronism type III with KCNJ5 gene mutation: a patient report and review of the literature. Hormone Research in Poediatrics 82 138-142. (doi:10.1159/000358197)

Aglony M, Martinez-Aguayo A, Carvajal CA, Campino C, Garcia H, Bancalari R, Bolte L, Avalos C, Loureiro C, Trejo P et al. 2011 Frequency of familial hyperaldosteronism type 1 in a hypertensive pediatric

http://joe.endocrinology-journals.org DOI: 10.1530/JOE-14-0597
(C) 2015 Society for Endocrinology Printed in Great Britain population: clinical and biochemical presentation. Hypertension $\mathbf{5 7}$ 1117-1121. (doi:10.1161/HYPERTENSIONAHA.110.168740)

Akerstrom T, Crona J, Delgado Verdugo A, Starker LF, Cupisti K, Willenberg HS, Knoefel WT, Saeger W, Feller A, Ip J et al. 2012 Comprehensive re-sequencing of adrenal aldosterone producing lesions reveal three somatic mutations near the KCNJ5 potassium channel selectivity filter. PLOS ONE 7 e41926. (doi:10.1371/journal.pone.0041926)

Aritomi S, Konda T \& Yoshimura M 2012 L/N-type calcium channel blocker suppresses reflex aldosterone production induced by antihypertensive action. Heart and Vessels 27 419-423. (doi:10.1007/s00380-011-0191-8)

Azizan EA, Lam BY, Newhouse SJ, Zhou J, Kuc RE, Clarke J, Happerfield L, Marker A, Hoffman GJ \& Brown MJ 2012 Microarray, qPCR, and KCNJ5 sequencing of APAs reveal differences in genotype and phenotype between zona glomerulosa- and zona fasciculata-like tumors. Journal of Clinical Endocrinology and Metabolism 97 E819-E829. (doi:10.1210/ jc.2011-2965)

Azizan EA, Poulsen H, Tuluc P, Zhou J, Clausen MV, Lieb A, Maniero C, Garg S, Bochukova EG, Zhao W et al. 2013 Somatic mutations in ATP1A1 and CACNA1D underlie a common subtype of adrenal hypertension. Nature Genetics 45 1055-1060. (doi:10.1038/ng.2716)

Ballantine DM, Klemm SA, Tunny TJ, Stowasser M \& Gordon RD $1996 a$ PCR-SSCP analysis of the p53 gene in tumours of the adrenal gland. Clinical and Experimental Pharmacology \& Physiology 23 582-583. (doi:10.1111/j.1440-1681.1996.tb02786.x)

Ballantine DM, Klemm SA, Tunny TJ, Stowasser M \& Gordon RD $1996 b$ PCR-SSCP analysis of the promoter region of the renin gene in patients with aldosterone-producing adenomas. Clinical and Experimental Pharmacology \& Physiology 23 584-586. (doi:10.1111/j.1440-1681. 1996.tb02787.x)

Bandulik S, Penton D, Barhanin J \& Warth R 2010 TASK1 and TASK3 potassium channels: determinants of aldosterone secretion and adrenocortical zonation. Hormone and Metabolic Research 42 450-457. (doi:10.1055/s-0029-1243601)

Bandulik S, Tauber P, Penton D, Schweda F, Tegtmeier I, Sterner C, Lalli E, Lesage F, Hartmann M, Barhanin J et al. 2013 Severe hyperaldosteronism in neonatal Task3 potassium channel knockout mice is associated with activation of the intraadrenal renin-angiotensin system. Endocrinology 154 2712-2722. (doi:10.1210/en.2013-1101)

Berthon A, Sahut-Barnola I, Lambert-Langlais S, de Joussineau C, Damon-Soubeyrand C, Louiset E, Taketo MM, Tissier F, Bertherat J, Lefrancois-Martinez AM et al. 2010 Constitutive $\beta$-catenin activation induces adrenal hyperplasia and promotes adrenal cancer development. Human Molecular Genetics 19 1561-1576. (doi:10.1093/hmg/ ddq029)

Berthon A, Drelon C, Ragazzon B, Boulkroun S, Tissier F, Amar L, Samson-Couterie B, Zennaro MC, Plouin PF, Skah S et al. 2014 WNT/ $\beta$-catenin signalling is activated in aldosterone-producing adenomas and controls aldosterone production. Human Molecular Genetics 23 889-905. (doi:10.1093/hmg/ddt484)

Beuschlein F, Boulkroun S, Osswald A, Wieland T, Nielsen HN, Lichtenauer UD, Penton D, Schack VR, Amar L, Fischer E et al. 2013 Somatic mutations in ATP1A1 and ATP2B3 lead to aldosteroneproducing adenomas and secondary hypertension. Nature Genetics $\mathbf{4 5}$ 440-444. (doi:10.1038/ng.2550)

Boulkroun S, Samson-Couterie B, Dzib JF, Lefebvre H, Louiset E, Amar L, Plouin PF, Lalli E, Jeunemaitre X, Benecke A et al. 2010 Adrenal cortex remodeling and functional zona glomerulosa hyperplasia in primary aldosteronism. Hypertension 56 885-892. (doi:10.1161/HYPERTENSIONAHA.110.158543)

Boulkroun S, Samson-Couterie B, Golib-Dzib JF, Amar L, Plouin PF, Sibony M, Lefebvre H, Louiset E, Jeunemaitre X, Meatchi T et al. 2011 Aldosterone-producing adenoma formation in the adrenal cortex involves expression of stem/progenitor cell markers. Endocrinology 152 4753-4763. (doi:10.1210/en.2011-1205)

Boulkroun S, Beuschlein F, Rossi GP, Golib-Dzib JF, Fischer E, Amar L, Mulatero P, Samson-Couterie B, Hahner S, Quinkler M et al. 2012 
Prevalence, clinical, and molecular correlates of KCNJ5 mutations in primary aldosteronism. Hypertension 59 592-598. (doi:10.1161/ HYPERTENSIONAHA.111.186478)

Boulkroun S, Golib Dzib JF, Samson-Couterie B, Rosa FL, Rickard AJ, Meatchi T, Amar L, Benecke A \& Zennaro MC 2013 KCNJ5 mutations in aldosterone producing adenoma and relationship with adrenal cortex remodeling. Molecular and Cellular Endocrinology 371 221-227. (doi:10.1016/j.mce.2013.01.018)

Calhoun DA, Nishizaka MK, Zaman MA, Thakkar RB \& Weissmann P 2002 Hyperaldosteronism among black and white subjects with resistant hypertension. Hypertension 40 892-896. (doi:10.1161/01.HYP. 0000040261.30455.B6)

Carvajal CA, Campino C, Martinez-Aguayo A, Tichauer JE, Bancalari R, Valdivia C, Trejo P, Aglony M, Baudrand R, Lagos CF et al. 2012 A new presentation of the chimeric CYP11B1/CYP11B2 gene with low prevalence of primary aldosteronism and atypical gene segregation pattern. Hypertension 59 85-91. (doi:10.1161/HYPERTENSIONAHA. 111.180513)

Charmandari E, Sertedaki A, Kino T, Merakou C, Hoffman DA, Hatch MM, Hurt DE, Lin L, Xekouki P, Stratakis CA et al. 2012 A novel point mutation in the KCNJ5 gene causing primary hyperaldosteronism and early-onset autosomal dominant hypertension. Journal of Clinical Endocrinology and Metabolism 97 E1532-E1539. (doi:10.1210/ jc.2012-1334)

Choi M, Scholl UI, Yue P, Bjorklund P, Zhao B, Nelson-Williams C, Ji W, Cho Y, Patel A, Men CJ et al. $2011 \mathrm{~K}+$ channel mutations in adrenal aldosterone-producing adenomas and hereditary hypertension. Science 331 768-772. (doi:10.1126/science.1198785)

Davies E, Bonnardeaux A, Plouin PF, Corvol P \& Clauser E 1997 Somatic mutations of the angiotensin II (AT1) receptor gene are not present in aldosterone-producing adenoma. Journal of Clinical Endocrinology and Metabolism 82 611-615.

Davies LA, Hu C, Guagliardo NA, Sen N, Chen X, Talley EM, Carey RM, Bayliss DA \& Barrett PQ 2008 TASK channel deletion in mice causes primary hyperaldosteronism. PNAS 105 2203-2208. (doi:10.1073/pnas. 0712000105)

Dekkers T, ter Meer M, Lenders JW, Hermus AR, Schultze Kool L, Langenhuijsen JF, Nishimoto K, Ogishima T, Mukai K, Azizan EA et al. 2014 Adrenal nodularity and somatic mutations in primary aldosteronism: one node is the culprit? Journal of Clinical Endocrinology and Metabolism 99 E1341-E1351. (doi:10.1210/jc.2013-4255)

Dluhy RG \& Lifton RP 1995 Glucocorticoid-remediable aldosteronism (GRA): diagnosis, variability of phenotype and regulation of potassium homeostasis. Steroids 60 48-51. (doi:10.1016/0039-128X(94)00010-A)

Doi M, Takahashi Y, Komatsu R, Yamazaki F, Yamada H, Haraguchi S, Emoto N, Okuno Y, Tsujimoto G, Kanematsu A et al. 2010 Salt-sensitive hypertension in circadian clock-deficient Cry-null mice involves dysregulated adrenal Hsd3b6. Nature Medicine 16 67-74. (doi:10.1038/nm.2061)

Doi M, Satoh F, Maekawa T, Nakamura Y, Fustin JM, Tainaka M, Hotta Y, Takahashi Y, Morimoto R, Takase K et al. 2014 Isoform-specific monoclonal antibodies against 3ß-hydroxysteroid dehydrogenase/ isomerase family provide markers for subclassification of human primary aldosteronism. Journal of Clinical Endocrinology and Metabolism 99 E257-E262. (doi:10.1210/jc.2013-3279)

Douma S, Petidis K, Doumas M, Papaefthimiou P, Triantafyllou A, Kartali N, Papadopoulos N, Vogiatzis K \& Zamboulis C 2008 Prevalence of primary hyperaldosteronism in resistant hypertension: a retrospective observational study. Lancet 371 1921-1926. (doi:10.1016/S01406736(08)60834-X)

Enberg U, Volpe C, Hoog A, Wedell A, Farnebo LO, Thoren M \& Hamberger B 2004 Postoperative differentiation between unilateral adrenal adenoma and bilateral adrenal hyperplasia in primary aldosteronism by mRNA expression of the gene CYP11B2. European Journal of Endocrinology 151 73-85. (doi:10.1530/eje.0.1510073)
Fardella CE, Pinto M, Mosso L, Gomez-Sanchez C, Jalil J \& Montero J 2001 Genetic study of patients with dexamethasone-suppressible aldosteronism without the chimeric CYP11B1/CYP11B2 gene. Journal of Clinical Endocrinology and Metabolism 86 4805-4807. (doi:10.1210/ jcem.86.10.7920)

Felizola SJ, Maekawa T, Nakamura Y, Satoh F, Ono Y, Kikuchi K, Aritomi S, Ikeda K, Yoshimura M, Tojo K et al. 2014 Voltage-gated calcium channels in the human adrenal and primary aldosteronism. Journal of Steroid Biochemistry and Molecular Biology 144 Pt B 410-416. (doi:10.1016/j.jsbmb.2014.08.012)

Fernandes-Rosa FL, Williams TA, Riester A, Steichen O, Beuschlein F, Boulkroun S, Strom TM, Monticone S, Amar L, Meatchi T et al. 2014 Genetic spectrum and clinical correlates of somatic mutations in aldosterone-producing adenoma. Hypertension 64 354-361. (doi:10.1161/HYPERTENSIONAHA.114.03419)

Freel EM, Mark PB, Weir RA, McQuarrie EP, Allan K, Dargie HJ, McClure JD, Jardine AG, Davies E \& Connell JM 2012 Demonstration of blood pressure-independent noninfarct myocardial fibrosis in primary aldosteronism: a cardiac magnetic resonance imaging study. Circulation. Cardiovascular Imaging 5 740-747. (doi:10.1161/CIRCIMAGING.112.974576)

Funder JW, Carey RM, Fardella C, Gomez-Sanchez CE, Mantero F, Stowasser M, Young WF Jr \& Montori VM 2008 Case detection, diagnosis, and treatment of patients with primary aldosteronism: an endocrine society clinical practice guideline. Journal of Clinical Endocrinology and Metabolism 93 3266-3281. (doi:10.1210/jc.20080104)

Gates LJ, Benjamin N, Haites NE, MacConnachie AA \& McLay JS 2001 Is random screening of value in detecting glucocorticoid-remediable aldosteronism within a hypertensive population? Journal of Human Hypertension 15 173-176. (doi:10.1038/sj.jhh.1001152)

Geller DS, Zhang J, Wisgerhof MV, Shackleton C, Kashgarian M \& Lifton RP 2008 A novel form of human mendelian hypertension featuring nonglucocorticoid-remediable aldosteronism. Journal of Clinical Endocrinology and Metabolism 93 3117-3123. (doi:10.1210/jc.2008-0594)

Gomez-Sanchez CE 2014 Channels and pumps in aldosterone-producing adenomas. Journal of Clinical Endocrinology and Metabolism 99 1152-1156. (doi:10.1210/jc.2014-1062)

Gordon RD, Stowasser M, Tunny TJ, Klemm SA, Finn WL \& Krek AL 1991 Clinical and pathological diversity of primary aldosteronism, including a new familial variety. Clinical and Experimental Pharmacology \& Physiology 18 283-286. (doi:10.1111/j.1440-1681.1991.tb01446.x)

Guagliardo NA, Yao J, Hu C \& Barrett PQ 2012a Minireview: aldosterone biosynthesis: electrically gated for our protection. Endocrinology 153 3579-3586. (doi:10.1210/en.2012-1339)

Guagliardo NA, Yao J, Hu C, Schertz EM, Tyson DA, Carey RM, Bayliss DA \& Barrett PQ 2012b TASK-3 channel deletion in mice recapitulates lowrenin essential hypertension. Hypertension 59 999-1005. (doi:10.1161/ HYPERTENSIONAHA.111.189662)

Hannemann A \& Wallaschofski H 2012 Prevalence of primary aldosteronism in patient's cohorts and in population-based studies - a review of the current literature. Hormone and Metabolic Research 44 157-162. (doi:10.1055/s-0031-1295438)

Heitzmann D, Derand R, Jungbauer S, Bandulik S, Sterner C, Schweda F, El Wakil A, Lalli E, Guy N, Mengual R et al. 2008 Invalidation of TASK1 potassium channels disrupts adrenal gland zonation and mineralocorticoid homeostasis. EMBO Journal 27 179-187. (doi:10.1038/sj. emboj.7601934)

Jackson RV, Lafferty A, Torpy DJ \& Stratakis C 2002 New genetic insights in familial hyperaldosteronism. Annals of the New York Academy of Sciences 970 77-88. (doi:10.1111/j.1749-6632.2002.tb04414.x)

Jeske YW, So A, Kelemen L, Sukor N, Willys C, Bulmer B, Gordon RD, Duffy D $\&$ Stowasser M 2008 Examination of chromosome 7p22 candidate genes RBaK, PMS2 and GNA12 in familial hyperaldosteronism type II. Clinical and Experimental Pharmacology \& Physiology 35 380-385. (doi:10.1111/j.1440-1681.2008.04882.x) 
Jin W, Klem AM, Lewis JH \& Lu Z 1999 Mechanisms of inward-rectifier K+ channel inhibition by tertiapin-Q. Biochemistry 38 14294-14301. (doi:10.1021/bi991206j)

Kitamoto T, Suematsu S, Matsuzawa Y, Saito J, Omura M \& Nishikawa T 2014 Comparison of cardiovascular complications in patients with and without KCNJ5 gene mutations harboring aldosterone-producing adenomas. Journal of Atherosclerosis and Thrombosis 21 [in press]. (doi:10.5551/jat.24455)

Lafferty AR, Torpy DJ, Stowasser M, Taymans SE, Lin JP, Huggard P, Gordon RD \& Stratakis CA 2000 A novel genetic locus for low renin hypertension: familial hyperaldosteronism type II maps to chromosome 7 (7p22). Journal of Medical Genetics 37 831-835. (doi:10.1136/ jmg.37.11.831)

Lenzini L, Seccia TM, Aldighieri E, Belloni AS, Bernante P, Giuliani L, Nussdorfer GG, Pessina AC \& Rossi GP 2007 Heterogeneity of aldosterone-producing adenomas revealed by a whole transcriptome analysis. Hypertension 50 1106-1113. (doi:10.1161/HYPERTENSIONAHA.107.100438)

Lenzini L, Caroccia B, Campos AG, Fassina A, Belloni AS, Seccia TM, Kuppusamy M, Ferraro S, Skander G, Bader M et al. 2014 Lower expression of the TWIK-related acid-sensitive $\mathrm{K}+$ channel 2 (TASK-2) gene is a hallmark of aldosterone-producing adenoma causing human primary aldosteronism. Journal of Clinical Endocrinology and Metabolism 99 E674-E682. (doi:10.1210/jc.2013-2900)

Lifton RP, Dluhy RG, Powers M, Rich GM, Cook S, Ulick S \& Lalouel JM 1992 A chimaeric $11 \beta$-hydroxylase aldosterone synthase gene causes glucocorticoid-remediable aldosteronism and human hypertension. Nature 355 262-265. (doi:10.1038/355262a0)

Litchfield WR, Anderson BF, Weiss RJ, Lifton RP \& Dluhy RG 1998 Intracranial aneurysm and hemorrhagic stroke in glucocorticoidremediable aldosteronism. Hypertension 31 445-450. (doi:10.1161/01. HYP.31.1.445)

Medeau V, Assie G, Zennaro MC, Clauser E, Plouin PF \& Jeunemaitre X $2005 a$ Familial aspect of primary hyperaldosteronism: analysis of families compatible with primary hyperaldosteronism type 2 . Annales d'Endocrinologie 66 240-246. (doi:10.1016/S0003-4266(05)81756-1)

Medeau V, Assié G, Zennaro M-C, Clauser E, Plouin P-F \& Jeunemaitre X $2005 \mathrm{~b}$ Familial aspects of primary aldosteronism: investigation of possible FH1 families. Annales d'Endocrinologie 66 1-7. (doi:10.1016/ S0003-4266(05)81756-1)

Monticone S, Hattangady NG, Nishimoto K, Mantero F, Rubin B, Cicala MV, Pezzani R, Auchus RJ, Ghayee HK, Shibata H et al. 2012 Effect of KCNJ5 mutations on gene expression in aldosteroneproducing adenomas and adrenocortical cells. Journal of Clinical Endocrinology and Metabolism 97 E1567-E1572. (doi:10.1210/jc. 2011-3132)

Monticone S, Hattangady NG, Penton D, Isales CM, Edwards MA, Williams TA, Sterner C, Warth R, Mulatero P \& Rainey WE 2013 A novel Y152C KCNJ5 mutation responsible for familial hyperaldosteronism type III. Journal of Clinical Endocrinology and Metabolism 98 E1861-E1865. (doi:10.1210/jc.2013-2428)

Monticone S, Else T, Mulatero P, Williams TA \& Rainey WE 2014 Understanding primary aldosteronism: impact of next generation sequencing and expression profiling. Molecular and Cellular Endocrinology 399C 311-320. (doi:10.1016/j.mce.2014.09.015)

Mulatero P, Tizzani D, Viola A, Bertello C, Monticone S, Mengozzi G, Schiavone D, Williams TA, Einaudi S, La Grotta A et al. 2011 Prevalence and characteristics of familial hyperaldosteronism: the PATOGEN study (primary aldosteronism in Torino-genetic forms). Hypertension 58 797-803. (doi:10.1161/HYPERTENSIONAHA.111.175083)

Mulatero P, Tauber P, Zennaro MC, Monticone S, Lang K, Beuschlein F, Fischer E, Tizzani D, Pallauf A, Viola A et al. 2012 KCNJ5 mutations in European families with nonglucocorticoid remediable familial hyperaldosteronism. Hypertension 59 235-240. (doi:10.1161/HYPERTENSIONAHA.111.183996)
Mulatero P, Monticone S, Bertello C, Viola A, Tizzani D, Iannaccone A, Crudo V, Burrello J, Milan A, Rabbia F et al. 2013 Long-term cardio- and cerebrovascular events in patients with primary aldosteronism. Journal of Clinical Endocrinology and Metabolism 98 4826-4833. (doi:10.1210/jc.2013-2805)

Murthy M, Xu S, Massimo G, Wolley M, Gordon RD, Stowasser M \& O'Shaughnessy KM 2014 Role for germline mutations and a rare coding single nucleotide polymorphism within the KCNJ5 potassium channel in a large cohort of sporadic cases of primary aldosteronism. Hypertension 63 783-789. (doi:10.1161/HYPERTENSIONAHA.113. 02234)

Nakamura Y, Maekawa T, Felizola SJ, Satoh F, Qi X, Velarde-Miranda C, Plonczynski MW, Ise K, Kikuchi K, Rainey WE et al. 2014 Adrenal CYP11B1/2 expression in primary aldosteronism: immunohistochemical analysis using novel monoclonal antibodies. Molecular and Cellular Endocrinology 392 73-79. (doi:10.1016/j.mce.2014.05.002)

Nanba K, Tsuiki M, Sawai K, Mukai K, Nishimoto K, Usui T, Tagami T, Okuno H, Yamamoto T, Shimatsu A et al. 2013 Histopathological diagnosis of primary aldosteronism using CYP11B2 immunohistochemistry. Journal of Clinical Endocrinology and Metabolism 98 1567-1574. (doi:10.1210/jc.2012-3726)

New M 1980 Hypertension of childhood with suppressed renin. Endocrine Reviews 1 421-430. (doi:10.1210/edrv-1-4-421)

Nishimoto K, Nakagawa K, Li D, Kosaka T, Oya M, Mikami S, Shibata H, Itoh H, Mitani F, Yamazaki T et al. 2010 Adrenocortical zonation in humans under normal and pathological conditions. Journal of Clinical Endocrinology and Metabolism 95 2296-2305. (doi:10.1210/ jc.2009-2010)

Oki K, Plonczynski MW, Luis Lam M, Gomez-Sanchez EP \& Gomez-Sanchez CE 2012a Potassium channel mutant KCNJ5 T158A expression in HAC-15 cells increases aldosterone synthesis. Endocrinology 153 1774-1782. (doi:10.1210/en.2011-1733)

Oki K, Plonczynski M, Lam M, Gomez-Sanchez E \& Gomez-Sanchez C $2012 b$ The potassium channel, Kir3.4 participates in angiotensin II-stimulated aldosterone production by a human adrenocortical cell line. Endocrinology 153 4328-4335. (doi:10.1210/en.2012-1241)

Ono Y, Nakamura Y, Maekawa T, Felizola SJ, Morimoto R, Iwakura Y, Kudo M, Seiji K, Takase K, Arai Y et al. 2014 Different expression of $11 \beta$-hydroxylase and aldosterone synthase between aldosteroneproducing microadenomas and macroadenomas. Hypertension 64 438-444. (doi:10.1161/HYPERTENSIONAHA.113.02944)

Osswald A, Fischer E, Degenhart C, Quinkler M, Bidlingmaier M, Pallauf A, Lang K, Mussack T, Hallfeldt K, Beuschlein F et al. 2013 Lack of influence of somatic mutations on steroid gradients during adrenal vein sampling in aldosterone-producing adenoma patients. European Journal of Endocrinology 169 657-663. (doi:10.1530/EJE-13-0551)

Pallauf A, Schirpenbach C, Zwermann O, Fischer E, Morak M, HolinskiFeder E, Hofbauer L, Beuschlein F \& Reincke M 2012 The prevalence of familial hyperaldosteronism in apparently sporadic primary aldosteronism in Germany: a single center experience. Hormone and Metabolic Research 44 215-220. (doi:10.1055/s-0031-1299730)

Pardo-Manuel de Villena F \& Sapienza C 2001a Nonrandom segregation during meiosis: the unfairness of females. Mammalian Genome 12 331-339. (doi:10.1007/s003350040003)

Pardo-Manuel de Villena F \& Sapienza C 2001 $b$ Transmission of robertsonian chromosomes through human female meiosis. Cytogenetics and Cell Genetics 92 342-344. (doi:10.1159/000056925)

Penton D, Bandulik S, Schweda F, Haubs S, Tauber P, Reichold M, Cong LD, El Wakil A, Budde T, Lesage F et al. 2012 Task3 potassium channel gene invalidation causes low renin and salt-sensitive arterial hypertension. Endocrinology 153 4740-4748. (doi:10.1210/en.2012-1527)

Pizzolo F, Trabetti E, Guarini P, Mulatero P, Ciacciarelli A, Blengio GS, Corrocher R \& Olivieri O 2005 Glucocorticoid remediable aldosteronism (GRA) screening in hypertensive patients from a primary care setting. Journal of Human Hypertension 19 325-327. (doi:10.1038/ sj.jhh.1001821) 
Romero DG, Yanes LL, de Rodriguez AF, Plonczynski MW, Welsh BL, Reckelhoff JF, Gomez-Sanchez EP \& Gomez-Sanchez CE 2007 Disabled-2 is expressed in adrenal zona glomerulosa and is involved in aldosterone secretion. Endocrinology 148 2644-2652. (doi:10.1210/ en.2006-1509)

Rossi GP, Sacchetto A, Pavan E, Palatini P, Graniero GR, Canali C \& Pessina AC 1997 Remodeling of the left ventricle in primary aldosteronism due to Conn's adenoma. Circulation 95 1471-1478. (doi:10.1161/01.CIR.95.6.1471)

Rossi GP, Bolognesi M, Rizzoni D, Seccia TM, Piva A, Porteri E, Tiberio GA, Giulini SM, Agabiti-Rosei E \& Pessina AC 2008 Vascular remodeling and duration of hypertension predict outcome of adrenalectomy in primary aldosteronism patients. Hypertension 51 1366-1371. (doi:10.1161/ HYPERTENSIONAHA.108.111369)

Rossi GP, Cesari M, Cuspidi C, Maiolino G, Cicala MV, Bisogni V, Mantero F \& Pessina AC 2013 Long-term control of arterial hypertension and regression of left ventricular hypertrophy with treatment of primary aldosteronism. Hypertension 62 62-69. (doi:10.1161/HYPERTENSIONAHA.113.01316)

Rossi GP, Cesari M, Letizia C, Seccia TM, Cicala MV, Zinnamosca L, Kuppusamy M, Mareso S, Sciomer S, Iacobone M et al. 2014 KCNJ5 gene somatic mutations affect cardiac remodelling but do not preclude cure of high blood pressure and regression of left ventricular hypertrophy in primary aldosteronism. Journal of Hypertension 32 1514-1521 discussion 1522. (doi:10.1097/HJH.0000000000000186)

Sakuma I, Suematsu S, Matsuzawa Y, Saito J, Omura M, Maekawa T, Nakamura Y, Sasano H \& Nishikawa T 2013 Characterization of steroidogenic enzyme expression in aldosterone-producing adenoma: a comparison with various human adrenal tumors. Endocrine Journal 60 329-336. (doi:10.1507/endocrj.EJ12-0270)

Savard S, Amar L, Plouin PF \& Steichen O 2013 Cardiovascular complications associated with primary aldosteronism: a controlled cross-sectional study. Hypertension 62 331-336. (doi:10.1161/ HYPERTENSIONAHA.113.01060)

Scholl UI, Nelson-Williams C, Yue P, Grekin R, Wyatt RJ, Dillon MJ, Couch R, Hammer LK, Harley FL, Farhi A et al. 2012 Hypertension with or without adrenal hyperplasia due to different inherited mutations in the potassium channel KCNJ5. PNAS 109 2533-2538. (doi:10.1073/pnas.1121407109)

Scholl UI, Goh G, Stolting G, de Oliveira RC, Choi M, Overton JD, Fonseca AL, Korah R, Starker LF, Kunstman JW et al. 2013 Somatic and germline CACNA1D calcium channel mutations in aldosteroneproducing adenomas and primary aldosteronism. Nature Genetics $\mathbf{4 5}$ 1050-1054. (doi:10.1038/ng.2695)

Seccia TM, Mantero F, Letizia C, Kuppusamy M, Caroccia B, Barisa M, Cicala MV, Miotto D \& Rossi GP 2012 Somatic mutations in the KCNJ5 gene raise the lateralization index: implications for the diagnosis of primary aldosteronism by adrenal vein sampling. Journal of Clinical Endocrinology and Metabolism 97 E2307-E2313. (doi:10.1210/ jc.2012-2342)

So A, Duffy DL, Gordon RD, Jeske YW, Lin-Su K, New MI \& Stowasser M 2005 Familial hyperaldosteronism type II is linked to the chromosome 7 p22 region but also shows predicted heterogeneity. Journal of Hypertension 23 1477-1484. (doi:10.1097/01.hjh.0000174299. 66369.26)

So A, Jeske YW, Gordon RD, Duffy D, Kelemen L \& Stowasser M 2006 No evidence for coding region mutations in the retinoblastoma-associated Kruppel-associated box protein gene (RBaK) causing familial hyperaldosteronism type II. Clinical Endocrinology 65 829-831. (doi:10.1111/ j.1365-2265.2006.02674.x)
Spat A \& Hunyady L 2004 Control of aldosterone secretion: a model for convergence in cellular signaling pathways. Physiological Reviews $\mathbf{8 4}$ 489-539. (doi:10.1152/physrev.00030.2003)

Staermose S, Marwick TH, Gordon RD, Cowley D, Dowling A \& Stowasser M 2009 Elevated serum interleukin 6 levels in normotensive individuals with familial hyperaldosteronism type 1. Hypertension 53 e31-e32. (doi:10.1161/HYPERTENSIONAHA.108.128512)

Stowasser M 2009 Update in primary aldosteronism. Journal of Clinical Endocrinology and Metabolism 94 3623-3630. (doi:10.1210/jc.20091399)

Stowasser M \& Gordon RD 2000 Primary aldosteronism: learning from the study of familial varieties. Journal of Hypertension 18 1165-1176.

Stowasser M \& Gordon RD 2001 Familial hyperaldosteronism. Journal of Steroid Biochemistry and Molecular Biology 78 215-229.

Stowasser M, Bachmann AW, Huggard PR, Rossetti TR \& Gordon RD 2000 Treatment of familial hyperaldosteronism type I: only partial suppression of adrenocorticotropin required to correct hypertension. Journal of Clinical Endocrinology and Metabolism 85 3313-3318. (doi:10.1210/ jcem.85.9.6834)

Stowasser M, Sharman J, Leano R, Gordon RD, Ward G, Cowley D \& Marwick TH 2005 Evidence for abnormal left ventricular structure and function in normotensive individuals with familial hyperaldosteronism type I. Journal of Clinical Endocrinology and Metabolism 90 5070-5076. (doi:10.1210/jc.2005-0681)

Sukor N, Mulatero P, Gordon RD, So A, Duffy D, Bertello C, Kelemen L, Jeske Y, Veglio F \& Stowasser M 2008 Further evidence for linkage of familial hyperaldosteronism type II at chromosome 7p22 in Italian as well as Australian and South American families. Journal of Hypertension 26 1577-1582. (doi:10.1097/HJH.0b013e3283028352)

Sutherland DJ, Ruse JL \& Laidlaw JC 1966 Hypertension, increased aldosterone secretion and low plasma renin activity relieved by dexamethasone. Canadian Medical Association Journal 95 1109-1119.

Taguchi R, Yamada M, Nakajima Y, Satoh T, Hashimoto K, Shibusawa N, Ozawa A, Okada S, Rokutanda N, Takata D et al. 2012 Expression and mutations of KCNJ5 mRNA in Japanese patients with aldosteroneproducing adenomas. Journal of Clinical Endocrinology and Metabolism 97 1311-1319. (doi:10.1210/jc.2011-2885)

Tanaka T, Tsutamoto T, Sakai H, Fujii M, Yamamoto T \& Horie M 2007 Comparison of the effects of efonidipine and amlodipine on aldosterone in patients with hypertension. Hypertension Research 30 691-697. (doi:10.1291/hypres.30.691)

Tauber P, Penton D, Stindl J, Humberg E, Tegtmeier I, Sterner C, Beuschlein F, Reincke M, Barhanin J, Bandulik S et al. 2014 Pharmacology and pathophysiology of mutated KCNJ5 found in adrenal aldosterone-producing adenomas. Endocrinology 155 1353-1362. (doi:10.1210/en.2013-1944)

Volpe C, Hoog A, Ogishima T, Mukai K, Lu M, Thoren M \& Hamberger B 2013 Immunohistochemistry improves histopathologic diagnosis in primary aldosteronism. Journal of Clinical Pathology 66 351-354. (doi:10.1136/jclinpath-2012-201287)

Williams TA, Monticone S, Crudo V, Warth R, Veglio F \& Mulatero P 2012 Visinin-like 1 is upregulated in aldosterone-producing adenomas with KCNJ5 mutations and protects from calcium-induced apoptosis. Hypertension 59 833-839. (doi:10.1161/HYPERTENSIONAHA.111. 188532)

Williams TA, Monticone S, Schack VR, Stindl J, Burrello J, Buffolo F, Annaratone L, Castellano I, Beuschlein F, Reincke M et al. 2014 Somatic ATP1A1, ATP2B3, and KCNJ5 mutations in aldosterone-producing adenomas. Hypertension 63 188-195. (doi:10.1161/HYPERTENSIONAHA.113.01733)

Received in final form 17 November 2014

Accepted 25 November 2014

Accepted Preprint published online 25 November 2014 http://joe.endocrinology-journals.org DOI: 10.1530/JOE-14-0597
Cㄱ 2015 Society for Endocrinology Printed in Great Britain 